\title{
Clipping and Japanese brome reduce western wheatgrass standing crop
}

\author{
MARSHALL R. HAFERKAMP, R.K. HEITSCHMIDT, AND MICHAEL G. KARL
}

Authors are rangeland scientist, supervisory rangeland scientist, and postdoctoral rangeland stientist USDA-ARS, Fort Keogh Livestock and Range Research Laboratory, Miles City, Mont. 59301.

\begin{abstract}
Japanese brome (Bromus japonicus Thunb.) and downy brome (Bromus tectorum I.), introduced annuals, have invaded many northern mixed-prairie plant communities. This study determined the effect of removing Japanese brome and clipping western wheatgrass [Pascopyrum smithii Rydb. (Love)] on aboveground forage production of a western wheatgrass dominated northern mixed-prairie community. During early spring 1993, a wet year, and 1995, a drier year, western wheatgrass tillers were clipped to ground level in May or June and Japanese brome seedlings were left undisturbed or removed in circular, $1-\mathrm{m}^{2}$ plots on a clay-pan field site. Western wheatgrass standing crop and tiller densities were estimated by clipping and counting in May and June, and these plus community standing crops were estimated in all plots after Japanese brome matured in mid July. Year effects were significant for standing crop and tiller density due to annual variation in amount and distribution of fall, spring, and early summer precipitation. Conditions were most favorable for tiller initiation of western wheatgrass and germination of annual brome seed in fall 1994 and for herbage production in 1993. Clipping western wheatgrass tillers reduced accumulated standing crop 230 to $350 \mathrm{~kg} \mathrm{ha}^{-1}$ and reduced tiller weight by 17 to $58 \%$. Standing crop of western wheatgrass was increased $102 \mathrm{~kg} \mathrm{ha}^{-1}$ with removal of Japanese brome, while total standing crop was reduced $284 \mathrm{~kg} \mathrm{ha}^{-1}$ with brome removal. Increased standing crop of western wheatgrass appeared to result from increased tiller density rather than increased tiller weight. Removal of Japanese brome from northern mixedprairie plant communities may increase production of associated perennial grasses, but managers should also expect a short-term decrease in total standing crop.
\end{abstract}

Key Words: Bromus japonicus, Pascopyrum smithii, Northern Great Plains, competition, defoliation, Agropyron smithii

The authors express appreciation to Bryon Bennett, Caralee Speelmon, Cheryl Murphy, and several summer aids for field assistance, Mary Ellen French for assistance with graphics, and Dr. Michael MacNeil for assistance with statistical analyses.

This paper is a contribution from the USDA/ARS and Montana Agricultural Experiment Station, Miles City, Mont.

USDA/ARS, Northern Plains Area, is an equal opportunity/affirmative action employer, and all agency services are available without discrimination.

Publication has been approved by the Director of the Montana Agr. Exp. Sta. Journal Ser. J-5129.

Manuscript accepted 10 Jan 98.
Japanese brome (Bromus japonicus Thunb.) and downy brome (Bromus tectorum L.), both introduced weedy grasses, have invaded thousands of hectares of Northern Great Plains rangeland over the past 30 years (Hewlett et al. 1981, Whisenant 1990 , Haferkamp et al. 1993). Management of rangelands dominated by annual grasses is difficult because annual plants avoid drought in the seed stage, and annual forage production fluctuates greatly from year to year with variations in precipitation (Gartner et al. 1986, Haferkamp et al. 1993) and soil nitrogen (Cline and Rickard 1973, McLendon and Redente 1994). The forage quality of annual grasses is comparable to perennial grasses at similar phenological stages. Because annual bromes mature earlier than perennial grasses, their presence can alter seasonal patterns of forage production and quality (Haferkamp et al. 1994), and mandate management changes for efficient use of infested rangelands.

Annual bromes reduce forage production of associated perennials, such as western wheatgrass (Pascopyrum smithii Rydb. (Love]). Competition from downy brome reduced plant height, number of tillers, foliage weight, root weight, and root length of western wheatgrass transplants (Rummell 1946). Presence of Japanese brome reduced standing crop of western wheatgrass through a reduction in tiller density in a northern mixed-prairie community in Montana (Haferkamp et al. 1997). Competition may also influence growth following defoliation to an equal or greater extent than the direct effects of defoliation (Briske and Richards 1995).

Many studies have shown forage production of western wheatgrass is decreased by heavy stocking (Hart and Balla 1982) and clipping (Whitman and Helgeson 1946, Branson 1956, Everson 1966, Buwai and Trlica 1977, Santos and Trlica 1978, Holderman and Goetz 1981). Although studies with other plant species have shown defoliation reduces the competitive ability of plants by reducing the effectiveness of resource acquisition, similar research has not been conducted with western wheatgrass and annual bromes. The objective of this research was to determine if clipping western wheatgrass tillers to ground level on key dates when livestock are put on rangelands (mid-May or mid-June) in the northern mixed prairie affected standing crop, tiller density, and tiller weight of western wheatgrass growing with Japanese brome.

\section{Materials and Methods}

\section{Study Site}

Research was conducted on the Fort Keogh Livestock and Range Research Laboratory $\left(46^{\circ} 22^{\prime} \mathrm{N} 105^{\circ} 5^{\prime} \mathrm{W}\right)$ near Miles City, Mont. Regional topography ranges from rolling hills to broken 
badlands with small intersecting ephemeral streams flowing into large rivers located in broad, nearly level valleys. Indigenous vegetation on the 22,500 -ha research station is a grama-needlegrass-wheatgrass (Bouteloua-Stipa-Agropyron) mix (Kuchler 1964). Annual precipitation averages $343 \mathrm{~mm}$, with about $60 \%$ received from April through September (Fig. 1). Daily temperature extremes range from $>38^{\circ} \mathrm{C}$ during summer to $<-40^{\circ} \mathrm{C}$ during winter. The average frost-free growing season is 150 days.

Soils at the site are a composite of Absher heavy clays (fine, montmorillonitic, Borollic Natrargids) and Gerdrum clay pans (Borollic Natrargids). Topography is gently sloping $(<2 \%)$. Vegetation is dominated by western wheatgrass, blue grama (Bouteloua gracilis [H.B.K.] Lag. ex Griffiths), Sandberg's bluegrass (Poa secunda Presl.), sand dropseed (Sporobolus cryptandrus [Torr.] Gray), and Japanese brome.

The study was conducted during the 1993 and 1995 growing scasons when Japanese brome was abundant due to favorable prestudy fall and spring growing conditions. Fall precipitation (1 September through 30 Novemher) is an important variable affecting abundance of annual bromes during the next growing season (Haferkamp et al. 1994). For example, fall precipitation in 1992 and 1994 was 12 and $20 \%$ (77 and $83 \mathrm{~mm}$ ), respectively, above the long-term $69 \mathrm{~mm}$ average (Fig. 2), and Japanese brome was abundant in spring 1993 and 1995. This is in contrast to spring 1994 when annual bromes were sparse, following $40 \%$ below average rainfall $(41 \mathrm{~mm})$ in fall 1993. Although the rainfall totals were similar in 1992 and 1994, distribution was not. In 1992, about $40 \%$ of the total precipitation fell during 2 events spanning; a 3-day period in September and a 4-day period in October, whereas in 1994, about $75 \%$ of the total fell during 3 events span-

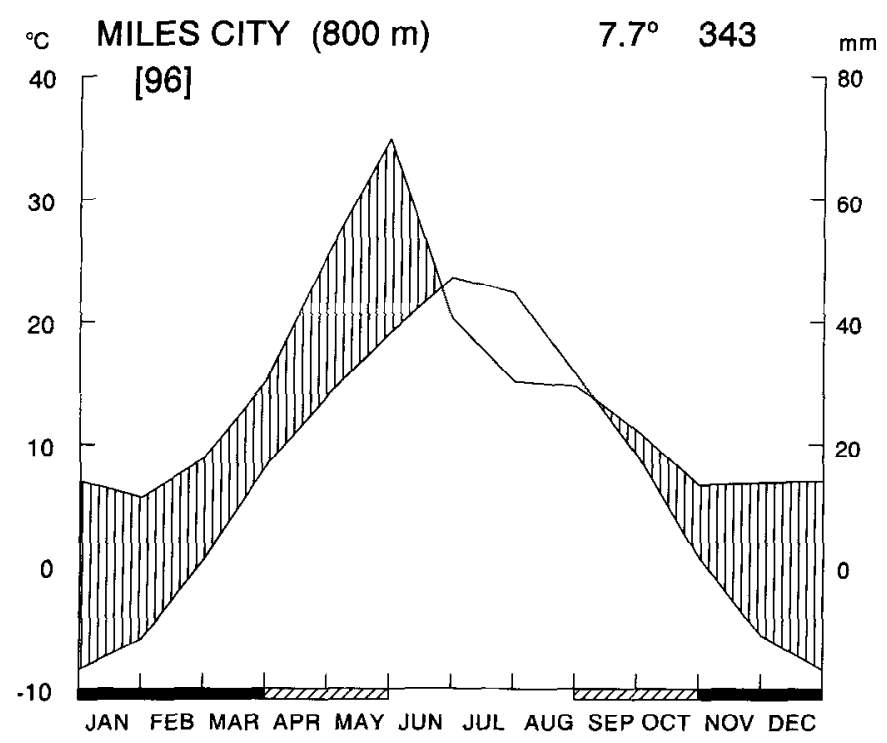

Fig. 1. Climate diagram for Miles City, Montana; mean monthly precipitation $(\mathrm{mm})$ and temperature $\left({ }^{\circ} \mathrm{C}\right)$ for 96-year period indicate mesic spring, early summer, and fall periods interrupted by late summer and early fall drought (stippling). Mean annual temperature is $7.7^{\circ} \mathrm{C}$, and mean annual precipitation is $343 \mathrm{~mm}$. Winter precipitation occurs as snow. Months shaded in black have average minimum temperatures $<0^{\circ} \mathrm{C}$. Those with diagonal lines have absolute minimum temperatures $<0^{\circ} \mathrm{C}$. Figure follows standard form of Walter (1985).
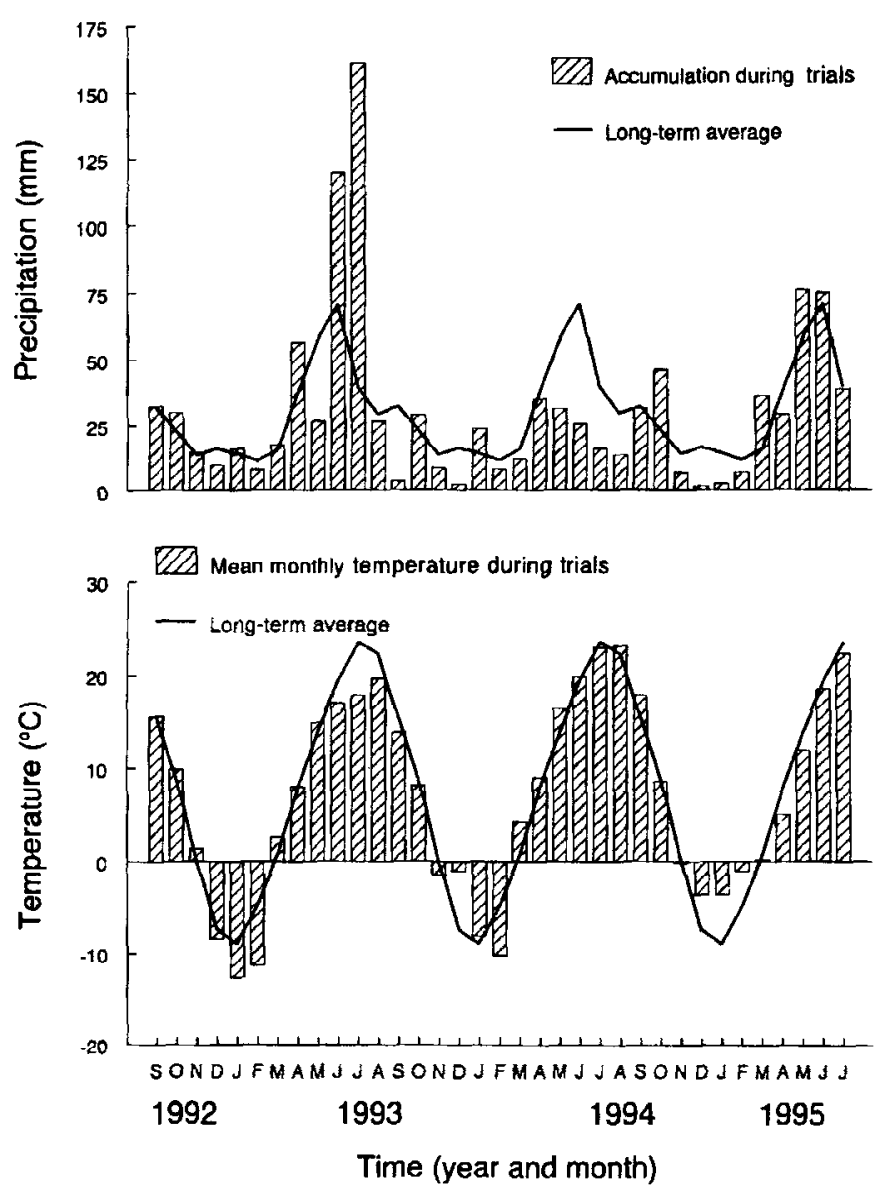

Fig. 2. (A) Monthly precipitation (bars) and 96-year average (solid line) and (B) average monthly temperature (bars) and long-term average (solid line) at the Frank Wiley Airfield (NOAA 1992-95) located about $11 \mathrm{~km}$ from the study plots.

ning; a 6-day period in September, and 3- and 11-day periods in October. Precipitation from 1 April through mid-July totaled 283 $\mathrm{mm}$ in 1993 and $211 \mathrm{~mm}$ in 1995 compared to the long-term 164mm average (NOAA 1992-1995). Precipitation during the sampling intervals of 1 April to mid-May, mid-May to mid-June, and mid-June to mid-July totaled 76,98 , and $109 \mathrm{~mm}$ in 1993 and 45 , 85 , and $81 \mathrm{~mm}$ in 1995.

Japanese brome seedlings were abundant by March 1993 and 1995. Inflorescences emerged in May, and seeds ripened in midJune. Most plants were senesced by early to mid-July. Western wheatgrass tillers began emerging in March and April. Tillers remained in the 4- to 6-leaf stage throughout the growing season, but few produced inflorescences.

\section{Experimental Design and Methods}

A new study location was selected within a common site each spring. Selection was based on presence of a uniform residual standing crop and emerging shoots of Japanese brome and western wheatgrass as determined by ocular estimate. Experimental design was a randomized complete-block with 6 treatments randomly assigned in a factorial arrangement in each of 10 blocks. Each block was located within a uniform stand of Japanese brome and western wheatgrass. Treatments applied in circular, $1-\mathrm{m}^{2}$ plots 
Table 1. Degrees of freedom (df), mean square (MS), and significance levels for analysis of variance models used to statistically analyze western wheatgrass variables at the initial, final, and accumulated harvests.

\begin{tabular}{|c|c|c|c|c|c|c|c|c|c|}
\hline \multirow[b]{3}{*}{ Model } & \multirow[b]{3}{*}{ df } & \multicolumn{3}{|c|}{ Initial harvest } & \multicolumn{3}{|c|}{ Final harvest } & \multicolumn{2}{|c|}{ Accumulated harvests } \\
\hline & & $\begin{array}{l}\text { Standing } \\
\text { crop }\end{array}$ & $\begin{array}{c}\text { Tiller } \\
\text { density }\end{array}$ & $\begin{array}{l}\text { Weight/ } \\
\text { tiller }\end{array}$ & $\begin{array}{l}\text { Standing } \\
\text { crop }\end{array}$ & $\begin{array}{c}\text { Tiller } \\
\text { density }\end{array}$ & $\begin{array}{l}\text { Weight } \\
\text { tiller }\end{array}$ & $\begin{array}{l}\text { Standing } \\
\text { crop }\end{array}$ & $\begin{array}{l}\text { Weight/ } \\
\text { tiller }\end{array}$ \\
\hline & & MS & MS & MS & MS & MS & MS & MS & MS \\
\hline Year (Y) & 1 & 113 & $228,290 * *$ & $0.0764^{* *}$ & 1 & 3,921 & 0.0026 & 71 & $0.0316^{* *}$ \\
\hline Block (Year) & 18 & 39 & 19,369 & 0.0016 & 79 & 6,887 & 0.0008 & 239 & 0.0011 \\
\hline Clip (C) & 2 & $3,458 * *$ & 5,181 & $0.1015^{* *}$ & $7,625 * *$ & $185,634 * *$ & $0.1285^{* *}$ & $850^{* *}$ & $0.1011 * *$ \\
\hline $\mathrm{Y}^{*} \mathrm{C}$ & 2 & 43 & $14,635^{*}$ & 0.0017 & 39 & $34,555^{* *}$ & $0.0274 * *$ & 5 & $0.0092 * *$ \\
\hline Rermoval (R) & 1 & $197^{*}$ & $8,738^{*}$ & 0.0003 & $234^{*}$ & $26,463^{* *}$ & 0.0000 & $409 * *$ & 0.0003 \\
\hline $\mathrm{Y} * \mathrm{R}$ & 1 & 70 & 4,966 & 0.0001 & 3 & 90 & 0.0001 & 46 & 0.0000 \\
\hline $\mathrm{C} * \mathrm{R}$ & 2 & 53 & 1,929 & 0.0018 & 76 & 6,926 & 0.0027 & 23 & 0.0018 \\
\hline $\mathrm{Y}^{*} \mathrm{C}^{*} \mathrm{R}$ & 2 & 2 & 1,238 & 0.0009 & 25 & 2,323 & 0.0008 & 16 & 0.0012 \\
\hline Error & 90 & 41 & 2,163 & 0.0008 & 44 & 2,445 & 0.0010 & 48 & 0.0008 \\
\hline
\end{tabular}

*PS0.05.

$* * \mathrm{P} \leq 0.01$

${ }^{1}$ Sum of initial (May or June) and end of season (July) standing crops.

included 3 western wheatgrass clipping treatments with 2 levels of Japanese brome. Western wheatgrass tillers were clipped at ground level initially in either mid-May or mid-June. Regrowth was clipped in these plots in mid-July. Control plots were clipped only at final harvest of all plots in mid-July. Japanese brome treatments were undisturbed or emerging seedlings were removed by hand several times from mid-April to mid-May in both years.

Standing crop and tiller density of western wheatgrass were estimated by clipping and counting in mid-May, mid-June, and mid-July. Western wheatgrass standing crop was at peak and Japanese brome was matured by the July date. Herbage was clipped at ground level by species in a circular, $0.25-\mathrm{m}^{2}$ subplot located at the center of each circular, $1-\mathrm{m}^{2}$ treatment plot. Herbage was oven-dried for 48 hours at $60^{\circ} \mathrm{C}$ before weighing.

\section{Statistical Analyses}

Analysis of variance was used to test the effect of years, clipping, and absence and presence of Japanese brome on standing crops and western wheatgrass tiller weights and densities. Effects of years was tested with the residual variation between blocks within year; effects of clipping, brome, and all interaction were tested with residual intra-block variation (Tables 1 and 2). The Least Significant Difference (LSD) method $(\mathrm{P} \leq 0.05)$ protected by a prior F-test $(\mathrm{P} \leq 0.05)$ was used for comparing treatment means. All differences discussed are significant at the $P \leq 0.05$ level unless otherwise noted.

\section{Results}

\section{Western Wheatgrass Response \\ Year}

Because amounts and distribution of fall and spring precipitation varied between years (Fig. 2), year effects were significant for various plant responses. Tiller densities at the initial and final harvest were greater in 1995 than in 1993, except for final harvest of the June clip treatment (Table 3). Weight per tiller was greater in 1993 (150 mg) than in 1995 (100 mg). Pre-harvest tiller densities were similar in May and June 1993 and increased in July, whereas, densities were greater in May than June but similar in July 1995 . Standing crop at the initial or final harvests or the sum of initial and final harvests were not significantly affected by year (Table 1).

Table 2. Degrees of freedom (df), mean square (MS), and significance levels for analysis of variance models used to statistically analyze standing crops for 2 years, 3 clipping treatments, and 2 brome removal treatments.

\begin{tabular}{|c|c|c|c|c|c|c|c|}
\hline \multirow[b]{3}{*}{ Model } & \multirow[b]{3}{*}{ df } & \multicolumn{5}{|c|}{ Standing crops } & \multirow[b]{2}{*}{ Forbs } \\
\hline & & Total & $\begin{array}{c}\text { Total } \\
\text { minus brome }\end{array}$ & $\begin{array}{l}\text { Japanese } \\
\text { brome }\end{array}$ & $\begin{array}{l}\text { Antual grass } \\
\text { minus brome }\end{array}$ & $\begin{array}{l}\text { Peremial grass minus } \\
\text { western wheatgrass }\end{array}$ & \\
\hline & & MS & MS & MS & MS & MS & MS \\
\hline Year (Y) & 1 & $2,515^{* *}$ & $4,845^{* *}$ & $182^{*}$ & $36^{* *}$ & $3,360 * *$ & $402^{* *}$ \\
\hline Block (Year) & 18 & 131 & 173 & 30 & 1 & 113 & 38 \\
\hline Clip (C) & 2 & $645^{* *}$ & $393 * *$ & 61 & 3 & 31 & 38 \\
\hline $\mathrm{Y} * \mathrm{C}$ & 2 & 119 & 123 & 2 & 3 & 36 & 34 \\
\hline Removal (R) & 1 & $1,516^{* *}$ & $1,092^{* *}$ & $4,419^{* *}$ & $30^{* *}$ & 77 & 16 \\
\hline $\mathrm{Y} * \mathrm{R}$ & 1 & 20 & 117 & $99 *$ & $28^{* *}$ & 57 & 101 \\
\hline $\mathrm{C} * \mathrm{R}$ & 2 & 103 & 46 & 29 & 2 & 36 & 34 \\
\hline $\mathrm{Y} * \mathrm{C} * \mathrm{R}$ & 2 & 3 & 1 & 7 & 3 & 7 & 34 \\
\hline Error & 90 & 64 & 66 & 21 & 2 & 24 & 29 \\
\hline
\end{tabular}

*P $\leq 0.05$.

$* * \mathrm{P} \leq 0.01$. 
Table 3. Western wheatgrass tiller densities $\left(\right.$ no. $\mathrm{m}^{-2}$ ) at initial and final harvests dates in 1993 and 1995 averaged across brome removal treatments.

\begin{tabular}{|c|c|c|c|c|}
\hline \multirow[b]{2}{*}{ Harvest } & \multirow[b]{2}{*}{ Year } & \multicolumn{3}{|c|}{ Initial clipping date } \\
\hline & & May & June & $\begin{array}{c}\text { Control } \\
\text { July }^{2}\end{array}$ \\
\hline Initial & $\begin{array}{l}1993 \\
1995\end{array}$ & $\begin{array}{l}412 \mathrm{~d}^{1} \\
935 \mathrm{a}\end{array}$ & $\begin{array}{l}\left.\text { o. } \mathrm{m}^{-2}\right) \\
492 \mathrm{~d} \\
781 \mathrm{~b}\end{array}$ & $\begin{array}{l}609 \mathrm{c} \\
845 \mathrm{ab}\end{array}$ \\
\hline Final (July) & $\begin{array}{l}1993 \\
1995\end{array}$ & $\begin{array}{l}438 d \\
571 \mathrm{c}\end{array}$ & $\begin{array}{r}100 \mathrm{e} \\
69 \mathrm{f}\end{array}$ & $\begin{array}{l}609 \mathrm{c} \\
845 a\end{array}$ \\
\hline
\end{tabular}

Means within a harvest followed by same letter are not siguificantly different $(\mathrm{P} \geq$ $0.05)$.

${ }^{2}$ Control plots were clipped only in July. Thus, initial equals final harvest values for control plots.

\section{Clipping}

Western wheatgrass standing crop averaged across years and brome removal treatments was $435 \mathrm{~kg} \mathrm{ha}^{-1}$ in May, $819 \mathrm{~kg} \mathrm{ha}^{-1}$ in June, and $1,179 \mathrm{~kg} \mathrm{ha}^{-1}$ in July, whereas weight per tiller was 80 $\mathrm{mg}, 140 \mathrm{mg}$, and $180 \mathrm{mg}$, respectively (data not shown). Western wheatgrass regrowth measured in July was greater in May $(379 \mathrm{~kg}$ $\left.\mathrm{ha}^{-1}\right)$ than June $\left(119 \mathrm{~kg} \mathrm{ha}^{-1}\right)$ clipped plots $(\mathrm{P} \leq 0.05)$ (data not shown). At the final harvest, western wheatgrass tiller densitics were greatest on control plots and least on plots clipped in June (Table 3). Trends for accumulated western wheatgrass standing crop and weight per tiller were similar (Table 4). Both were greatest on controls, least on May clipped plots, and intermediate on June clipped plots. Weight per tiller, however, varied in magnitude between years for the May and July clipping dates.

Table 4. Western wheatgrass weight/tiller ( $\mathrm{mg})$ and standing crop $\left(\mathrm{kg} \mathrm{ha}^{-1}\right)$ accumulated over the first and final harvests in 1993 and 1995.

\begin{tabular}{lcccc}
\hline & \multicolumn{4}{c}{ Initial clipping date } \\
\cline { 2 - 5 } Variable & Year & May & June & $\begin{array}{c}\text { Control } \\
\text { July }{ }^{2}\end{array}$ \\
\hline Weight/tiller (mg) & 1993 & $90 \mathrm{~d}$ & $120 \mathrm{c}$ & $206 \mathrm{a}$ \\
& 1995 & $60 \mathrm{e}$ & $120 \mathrm{c}$ & $144 \mathrm{~b}$ \\
$\begin{array}{l}\text { Standing crop } \\
\left(\mathrm{kg} \mathrm{ha}^{-1}\right)\end{array}$ & & $814 \mathrm{c}^{1}$ & $947 \mathrm{~b}$ & $1,179 \mathrm{a}$
\end{tabular}

Means within a variable followed by same letter are not significantly different (P $\geq$ 0.05 ).

${ }^{2}$ Standing crop determined in mid-July.

\section{Brome Removal}

Removal of Japanese brome increased the first and final harvest standing crop of western wheatgrass, as well as, accumulated standing crop (Table 5). Likewise tiller density was consistently greatest with brome removal at both the initial and final harvest dates (Table 5). However, presence or absence of brome did not affect tiller weight (Table 1). No significant interaction occurred between clipping treatment and presence or absence of brome for any western wheatgrass characteristic (Table 1).

\section{Community Response}

Averaged across clipping and brome removal treatments, standing crop of total vegetation, total vegetation minus Japanese brome, perennial grasses minus western wheatgrass, and forbs were greater in 1993 than 1995 (Table 6). Standing crop of
Table 5. Western wheatgrass standing crop ( $\left.\mathrm{kg} \mathrm{ha}^{-1}\right)$ and tiller densities (no. $\mathrm{m}^{-2}$ ) on date of initial or final harvests and accumulated (initial + regrowth) standing crop averaged across years and clipping treatments.

\begin{tabular}{|c|c|c|}
\hline \multirow[b]{2}{*}{ Variable } & \multicolumn{2}{|c|}{ Japanese brome } \\
\hline & Not removed & Removed \\
\hline Standing crop & \multicolumn{2}{|c|}{$\ldots \ldots \ldots\left(\mathrm{kgha}^{-1}\right) \ldots \ldots \ldots$} \\
\hline Initial harvest & $763 b^{1}$ & $865 a$ \\
\hline Final harvest & $503 b$ & $615 a$ \\
\hline \multirow[t]{2}{*}{ Accumulated harvests } & $906 \mathrm{~b}$ & $1,064 \mathrm{a}$ \\
\hline & \multicolumn{2}{|c|}{$\ldots\left(\right.$ no. $\left.m^{-2}\right) \ldots \ldots$} \\
\hline \multicolumn{3}{|l|}{ Tiller density } \\
\hline Initial harvest & $645 b$ & $713 a$ \\
\hline Final harvest & $413 b$ & $532 a$ \\
\hline
\end{tabular}

Japanese brome ( 600 vs. $429 \mathrm{~kg} \mathrm{ha}^{-1}$ ) and other annual grasses ( 84 vs. $2 \mathrm{~kg} \mathrm{ha}^{-1}$ ) were greater in 1995 than in 1993 on the undisturbed plots, but standing crop of brome averaged less than $30 \mathrm{~kg}$ $\mathrm{ha}^{-1}$, on plots where most brome was removed (data not shown). Clipping western wheatgrass in May or June reduced standing crop of total vegetation and total vegetation minus Japanese brome compared to controls (Table 7). Removing brome reduced standing crop of total vegetation but produced the greatest standing crop of total vegetation minus Japanese brome (Table 8). No significant interactions were detected between clipping and brome removal for any measurement (Table 2).

\section{Discussion}

Year

Significant main effects of year and interaction effects with clipping and brome removal resulted largely from annual variation in amount and distribution of fall, spring, and early summer precipitation (Fig. 2). Generally, the fall precipitation pattern was more favorable for initiation of western wheatgrass tillers and germination of annual brome seed in 1994 than in 1992. A dry May and wet June and July 1993 were reflected in an increase in western wheatgrass tiller density between June and July 1993. A wet May and June and drier July 1995 resulted in similar tiller densities from May through July 1995. Warmer spring temperatures, greater precipitation, and cooler temperatures during the growing season were more favorable for perennial herbage production and regrowth of May defoliated tillers in 1993 than in 1995. The

Table 6. Herbage standing crop $\left(\mathrm{kg} \mathrm{ha}^{-1}\right)$ in 1993 and 1995 averaged across clipping and brome removal treatments.

\begin{tabular}{lcc}
\hline \hline & \multicolumn{2}{c}{ Year } \\
\cline { 2 - 3 } Standing crop & 1993 & 1995 \\
\hline & $1,983 \mathrm{a}^{2}$ & $1,617 \mathrm{~b}$ \\
Total vegetation 1 & & \\
Total vegetation minus $^{\text {Japanese brome }}{ }^{1}$ & $1,759 \mathrm{a}$ & $1,251 \mathrm{~b}$ \\
Perennial grasses minus & & $136 \mathrm{~b}$ \\
$\quad \begin{array}{l}\text { Western wheatgrass } \\
\text { Forbs }\end{array}$ & $560 \mathrm{a}$ & $104 \mathrm{~b}$ \\
\hline
\end{tabular}

${ }_{1}$ Includes western wheatgrass accumulated standing crop (initial + final harvest) and standing crop of other species collected at final harvest in July.

${ }^{2}$ Means within a row followed by same letter are not significantly different $(P \geq 0.05)$ 
Table 7. Herbage standing crop (kg ha-1) for initial western wheatgrass clipping dates averaged across years and brome removal treatments.

\begin{tabular}{|c|c|c|c|}
\hline \multirow[b]{2}{*}{ Standing crop } & \multicolumn{3}{|c|}{ Initial clipping date } \\
\hline & May & June & $\begin{array}{c}\text { Control } \\
\text { July }\end{array}$ \\
\hline & \multicolumn{3}{|c|}{$\ldots \ldots \ldots\left(\mathrm{kg} \mathrm{ha}^{-1}\right) \ldots \ldots$} \\
\hline Total vegetation 1 & $1,752 b^{3}$ & $1,668 \mathrm{~b}$ & $1,979 \mathrm{a}$ \\
\hline \multicolumn{4}{|l|}{ Total vegetation minus } \\
\hline Japanese brome ${ }^{1}$ & $1,424 b$ & $1,442 b$ & $1,650 \mathrm{a}$ \\
\hline Japanese brome & $304 a$ & $215 b$ & 297a \\
\hline
\end{tabular}

Includes western wheatgrass accumulated standing crop (initial + final harvest) and standing crop of other species collected at final harvest in July.

${ }^{2}$ Means wirhin a row followed by same letters are not significantly different ( $P \geq 0.05$ ).

observed positive relationship between production of perennial and annual cool-season grasses and amounts of fall and spring precipitation has been reported by others (Sneva 1982, Smoliak 1986, White 1985, Whisenant 1990, Haferkamp et al. 1993).

\section{Clipping}

Differences in tiller densities and standing crops between harvest dates reflect the interval between clipping events and the environmental conditions during the initial growth and regrowth intervals. Clipping tillers earlier allowed plants to replace leaf area sooner; delaying clipping gave plants a longer period of uninterrupted growth. After clipping, tillers had little leaf tissue with which to manufacture tiller tissue. As leaf area increases, rate of photosynthesis and growth increase, assuming environmental conditions are adequate for growth. Reduction in standing crop of western wheatgrass with clipping, reflected in standing crop of total vegetation agrees with findings of Buwai and Trlica (1977), Santos and Trlica (1978), and Holderman and Goetz (1981). In contrast, Lauenroth et al. (1985) found no reduction in tiller density or biomass production of western wheatgrass measured on 15 August 1979 when a single light or heavy defoliation was applied on 20 May 1979 compared to an undefoliated control. Environmental conditions were not reported for that study, but must have been good to allow this type of compensatory growth. Hart and Balla (1982), however, showed that severity of tiller removal with grazing is often much less than that imposed in clipping treatments like those used in our study, and cautioned that plant responses to clipping treatments may be over-stated (over-estimated).

\section{Brome Removal}

Increases in standing crop of other herbage with removal of Japanese brome agrees with findings of others whether burning (Gartner et al. 1978, 1986), spraying with herbicides (Hewlett et

Table 8. Herbage standing crop $\left(\mathrm{kg} \mathrm{ha}^{-1}\right)$ with and without brome averaged across years and western wheatgrass clipping dates.

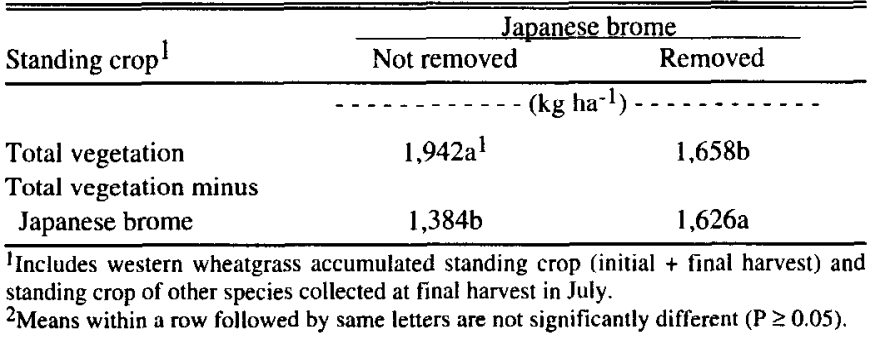

al. 1981), or hand plucking (Haferkamp et al. 1997) were used, and similar results have been reported for other species. For example, tiller recruitment of little bluestem (Schizachyrium scoparium [Michx.] Nash) increased $57 \%$ after removal of neighboring plants and $71 \%$ after removal of about one-half of the existing tillers within plants (Briske and Butler 1989).

With Japanese brome removed, the $250 \mathrm{~kg} \mathrm{ha}^{-1}$ increase in total standing crop did not entirely compensate for the lost brome production. Japanese brome standing crop was reduced 500 to 1,100 $\mathrm{kg} \mathrm{ha}^{-1}$ in earlier studies (Haferkamp et al. 1997) and $500 \mathrm{~kg} \mathrm{ha}^{-1}$ in the current study. Lack of compensation may have been a shortterm phenomena. Greater resource acquisition that might result from an increase in total root or rhizome volume of western wheatgrass might not be immediately apparent (Eissenstat and Caldwell 1989). The extent of western wheatgrass rhizome and root growth into areas previously occupied by Japanese brome was not determined in either of our studies (Haferkamp et al. 1997). Mueller (1941), however, reported that new rhizomes of western wheatgrass form concurrently with the shoots, provided there are adequate resources (e.g. carbohydrates, water, etc.) for growth.

\section{Clipping Date(s) by Brome Removal Interaction}

The lack of interaction of brome removal with clipping was contrary to findings from other studies with other species. Severe clipping of Idaho fescue (Festuca idahoensis [L.] Villars) and bluebunch wheatgrass (Pseudoroegneria spicata [Pursh.] A. Love) combined with reduced competition did not decrease production during the treatment year (Mueggler 1975). Idaho fescue withstood clipping well when competing vegetation was clipped. In contrast, Mueggler found vigor of bluebunch wheatgrass declined the second growing season as competing vegetation recovered. Archer and Detling (1984) found stembase biomass of defoliated tillers of big bluestem (Andropogon gerardii Vitt) decreased with full and reduced competition, but leaf biomass was less with full competition. Defoliated tillers of threadleaf sedge (Carex filifolia Nutt.) growing with full competition produced significantly less leaf biomass than tillers growing with reduced levels of competition. Plants in that study were measured in the year of treatment.

The relative effects of competition and herbivory on plant growth tend to increase on more productive sites. Herbivory has less effect than competition on plant growth on sites with low levels of productivity (Bonser and Reader 1995). In our study standing crop of vegetation, excluding western wheatgrass and Japanese brome averaged $572 \mathrm{~kg} \mathrm{ha}^{-1}$ when brome was removed and $478 \mathrm{~kg} \mathrm{ha}^{-1}$ where brome was undisturbed. This amount of herbage may have masked the interaction between clipping and Japanese brome removal. In other studies biomass of competing species was much less when plots were treated with tillage or clipping (Mueggler 1975, Archer and Detling 1984).

One might speculate the strongly-rhizomatous nature of western wheatgrass might also affect interaction responses between clipping and removal of Japanese brome. Bonham and Mack (1990) suggest the asexual reproductive strategy of western wheatgrass, where roots and rhizomes were distributed both vertically and laterally, enabled it to minimize detrimental effects of its association with winterfat (Eurotia lanata [Pursh] Moq.). Differences in herbivory tolerance between rhizomatous grasses and bunchgrasses, and among species within each group, is largely a function of meristem availability at the time of defoliation (Briske and Richards 1995). Rhizomatous species frequently pos- 
sess many active meristems throughout the growing season. These active shoot sinks rapidly sequester available carbon and nitrogen within the plant, incrcasing the relative rate of shoot growth after defoliation. Hull (1987) reported rhizomatous species are most severely impacted by defoliation when tiller densities are at a seasonal low. Few reports, however, exist in the literature describing long-term responses of western wheatgrass rhizomes to herbivory or competition. After grazing was excluded from their study area, Lauenroth et al. (1985) interpreted significant year-to-year increase in western wheatgrass rhizome weight, as an indication of recovery from grazing. Schuman et al. (1986) also suggested an increase in basal cover on a grazed western wheatgrass pasture may have been due to stimulation of rhizome production by grazing, but they also found an increase in basal cover on ungrazed control pastures.

\section{Conclusions and Management Implications}

Delaying grazing until July may improve herbage production, increase vigor of tillers, and sustain range health, but will probably compromise the well-being of grazing animals. Forage quality of herbage removed by early harvests would have been greater than with the late harvest. Heitschmidt et al. (1995) clearly showed that forage quality from clay pan and silty range sites was controlled by the age of plant tissue.

Standing crop of western wheatgrass increased $148 \mathrm{~kg} \mathrm{ha}^{-1}$ with removal of Japanese brome. The increase in forage appeared to result from an increase in tiller density and not an increase in weight per tiller. Tiller density increased as fall precipitation increased and with removal of Japanese brome. Together these could have increased availability of spring soil moisture. Tiller weight increased with increasing growing-season precipitation. The increase in western wheatgrass standing crop and reduction of total standing crop agrees with findings of Haferkamp et al. (1997). These increases occurred regardless of variation in associated species.

Although removal of Japanese brome from northern mixedprairic rangelands will increase production of associated perennial grasses, it will also produce at least a short-term reduction in total forage production. Grazing management tactics and variations in climatic and site conditions will probably also influence this relationship. Further research is needed to determine costs, benefits, and longevity of Japanese brome removal.

\section{Literature Cited}

Archer, S. and J.K. Detling. 1984. The effects of defoliation and competition on regrowth of tillers of two North American mixed-grass prairie graminoids. Oikos 43:351-357.

Bonham, C.D. and S.E. Mack. 1990. Root distribution of Eurotia lana $t a$ in association with two species of Agropyron on disturbed soils. Bot. Gaz. 151:522-527.

Bonser, S.P. and R.J. Reader. 1995. Plant competition and herbivory in relation to vegetation biomass. Ecol. 76:2176-2183.

Branson, F.A. 1956. Quantitative effect of clipping treatments on five range grasses. J. Range Manage. 9:86-88.

Briske, D.D. and J.L. Butler. 1989. Density-dependent regulation of ramet populations with the bunchgrass Schizachrium scoparium: Interclonal versus intraclonal interference. J. Ecol. 77:963-974.
Briske, D.D. and J.H. Richards. 1995. Plant responses to defoliation: A physiological, morphological, and demographic evaluation, $p$. 635-710. In: D.J. Bedunah and R.E. Sosebee (eds.), Wildland plants: Physiological ecology and developmental morphology. Soc. Range Manage. Denver, Colo.

Buwai, M. and M.J. Trlica. 1977. Multiple defoliation effects on herbage yield, vigor, and total nonstructural carbohydrates of five range species. J. Range Manage. 30:164-171.

Cline, J.F. and W.H. Rickard. 1973. Herbage yields in relation to soil water and assimilated nitrogen. J. Range Manage. 26:296-298.

Eissenstat, D.M. and M.M. Caldwell. 1989. Invasive root growth into disturbed soil of two tussock grasses that differ in competitive effectiveness. Funct. Ecol. 3:345-353.

Everson, A.C. 1966. Effects of frequent clipping at different stubble heights on western wheatgrass (Agropyron smithii Rydb.). Agron. J. 58:33-35.

Gartner, F.R., E.M. White, and R.I. Butterfield. 1986. Mechanical treatment and burning for high quality range forage, p. 135-140. In: South Dakota Bccf Rcport, Animal Range Sciences Dept., Agr. Exp. Sta., Coop. Ext. Serv., South Dakota State Univ., Brookings, S. Dak.

Gartner, F.R., R.I. Butterfield, W.W. Thompson, and L.R. Roath. 1978. Prescribed burning of range ecosystems in South Dakota, $p$. 687-690. In: D.N. Hyder (ed.) Proc. 1st Int. Rangeland Cong. Soc. Range Manage., Denver, Colo.

Haferkamp, M.R., M.G. Karl, and M.D. MacNeil. 1994. Influence of storage, temperature, and light on germination of Japanese brome seed. J. Range Manage. 47:140-144.

Haferkamp, M.R., R.K. Heitschmidt, and M.G. Karl. 1997. Influence of Japanese brome on western wheatgrass yield. J. Range Manage. 50:44-50.

Haferkamp, M.R., J.D. Volesky, M.M. Borman, R.K. Heitschmidt, and P.O. Currie. 1993. Effects of mechanical treatments and climatic factors on the productivity of Northern Great Plains rangelands. J. Range Manage. 46:346-350.

Hart, R.H. and E.F. Balla. 1982. Forage production and removal from western and crested wheatgrass under grazing. J. Range Manage. 35:362-366.

Heitschmidt, R.K., E.E. Grings, M.R. Haferkamp, and M.G. Karl. 1995. Herbage dynamics on 2 Northern Great Plains range sites. J. Range Manage. 48:211-217.

Hewlett, D.B., J.R. Johnson, R.I. Butterfield, and V.K. Mosley. 1981. Japanese brome response to atrazine in combination with nitrogen fertilizer in the mixed prairie. J. Range Manage. 34:22-25.

Holderman, C.A. and H. Goetz. 1981. Response of western North Dakota mixed prairie to intensive clipping and five stages of development. J. Range Manage. 34: 188-193.

Hull, R.J. 1987. Kentucky bluegrass photosynthate following scheduled mowing. J. Amer. Soc. Hort. Sci. 112:829-834.

Kuchler, A.W. 1964. Potential natural vegetation of the conterminous United States. Amer. Geog. Soc. Spec. Pub. 36. Amer. Geog. Soc. New York, N.Y.

Lauenroth, W.K., J.K. Detling, D.G. Milchunas, and J.L. Dodd. 1985. Impact of $\mathrm{SO}_{2}$ exposure on the response of Agropyron smithii to defoliation. J. Range Manage. 38:16-20.

McLendon, T. and E.F. Redente. 1994. Role of nitrogen availability in the transition from annual-dominated to perennial-dominated seral communities, p. 352-362. In: S.B. Monsen and S.G. Kitchen (compilers) Proc. Ecology and management of annual rangelands. 18-21 May 1992, Boise, Ida. USDA/FS Int. Res. Sta. Gen. Tech. Rep. INT-GTR313. Ogden, Ut.

Mueggler, W.F. 1975. Rate and pattern of vigor recovery in Idaho fescue and bluebunch wheatgrass. J. Range Manage. 28:198-204.

Mueller, I.M. 1941. An experimental study of rhizomes of certain prairie plants. Ecol. Monogr. 11:165-188.

National Oceanic and Atmospheric Administration. 1992-1995. Climatological data annual summary, Montana. 95-98:13.

Rummell, R.S. 1946. Some effects of competition from cheatgrass brome on crested wheatgrass and bluestem wheatgrass. Ecol. 27:159-167. 
Santos, G.L. and M.J. Trlica. 1978. Clipping effects on production and carbohydrate reserves of blue grama and western wheatgrass, $p$. 384-386. In: D.N. Hyder (ed.) Proc. 1st Int. Rangeland Cong. Soc. Range Manage. Denver, Colo.

Schuman, G.E., D.T. Booth, J.W. Waggoner, and F. Rauzi. 1986. The effect of grazing reclaimed mined lands on forage production and composition, p. 163-164. In: P.J. Joss et al. (eds.) Rangelands: A resource under siege Proc. 2nd Int. Rangeland Cong. Australian Academy of Sci., Canberra, ACT, Australia.

Smoliak, S. 1986. Influence of climatic conditions on production of Stipa-Bouteloua prairie over a 50-year period. J. Range Manage. 39:100-103.
Sneva, F.A. 1982. Relation of precipitation and temperature with yield of herbaceous plants in eastern Oregon. Int. J. Biometeoral. 6:263-276.

Walter, H. 1985. Vegetation of the earth and ecological systems of the geo-biosphere. Third, Revised and Enlarged Edition. Translated from the Fifth, Revised German Edition by O. Muise. Springer-Verlag, New York, N.Y

Whisenant, S.G. 1990. Postfire population dynamics of Bromus japonicus. Amer. Midl, Natur. 123:301-308.

White, L.M. 1985. Stand age, precipitation, and temperature effects on forage yield. J. Range Manage. 38:39-43.

Whitman, W.C. and E.A. Helgeson. 1946. Range vegetation studies. N. Dak. Agr. Exp. Sta. Bull. 340. Fargo, N. Dak. 